\title{
Development and application of a liquid chromatography-mass spectrometry method for the determination of sugars and organics acids in araza, ceriguela, guava, mango and pitanga
}

\author{
Desenvolvimento e aplicação de método por cromatografia \\ líquida-espectrometria de massas para determinação de \\ açúcares e ácidos orgânicos em araçá, ceriguela, goiaba, \\ manga e pitanga
}

Patricia Carvalho Cardoso ${ }^{1}$, Fernanda Sviech ${ }^{2 *}$ (D), Marcella Fernanda Alves Reis ${ }^{3}$, Amadeu Hoshi Iglesias ${ }^{3}$, Rafael Augustus Oliveira ${ }^{1}$, Job Ubbink ${ }^{4}$, Felix G. R. Reyes ${ }^{2}$, Ana Silvia Prata ${ }^{2}$

${ }^{1}$ Universidade Estadual de Campinas (UNICAMP), Faculdade de Engenharia Agrícola, Campinas/SP - Brasil

${ }^{2}$ Universidade Estadual de Campinas (UNICAMP), Faculdade de Engenharia de Alimentos, Campinas/SP - Brasil

${ }^{3}$ Apex Science Consultoria Analítica Ltda, Campinas/SP - Brasil

${ }^{4}$ University of Minneapolis, Department of Food Science and Nutrition, Saint Paul/MN - USA

${ }^{*}$ Corresponding Author: Fernanda Sviech, Universidade Estadual de Campinas (UNICAMP), Faculdade de Engenharia de Alimentos, Rua Monteiro Lobato, 80, CEP: 13083-862, Campinas/SP - Brasil, e-mail: f228134@dac.unicamp.br, fer_sviech@hotmail.com

Cite as: Cardoso, P. C., Sviech, F., Reis, M. F. A., Iglesias, A. H., Oliveira, R. A., Ubbink, J., Reyes, F. G. R., \& Prata, A. S. (2021). Development and application of a liquid chromatography-mass spectrometry method for the determination of sugars and organics acids in araza, ceriguela, guava, mango and pitanga. Brazilian Journal of Food Technology, 24, e2020169. https://doi.org/10.1590/1981-6723.16920

\begin{abstract}
The intrinsic characteristics of many tropical fruits cause high post-harvest losses and prevent their commercialization as fresh fruits. Information about their composition is crucial for defining processing conditions and identifying opportunities for product development. However, the analytical methods generally used to quantify sugars and organic acids are costly and time-consuming. Simultaneous analysis by Liquid Chromatography-Electrospray lonization-Mass Spectrometry (LC-ESI-MS/MS) is a very sensitive and reproducible technique, allowing for accurate simultaneous multianalyte quantitation in complex systems. Thus, a LC-ESI-MS/MS Multiple Reaction Monitoring (MRM) method was developed using reverse phase column for detecting and quantifying sugars and some organic acids in only $4 \mathrm{~min}$, in selected fruits as following: araza (Psidium cattleianum L.), ciriguela (Spondias purpurea L.), mango (Mangifera indica L.), guava (Psidium guajava L.) and pitanga (Eugenia uniflora L.). All fruits had a similar concentration of glucose and fructose, except for pitanga that presented higher values of both. The content of citric, malic and tartaric acids was quantitated; some fruits stood out by their high content of organic acids, for instance, araza was rich in citric acid. The
\end{abstract}


newly generated data on the composition of tropical fruits allowed establishing a correlation between the carbohydrate content and the physical properties of the fruit pulps, assist in product development.

Keywords: Food analysis; Food composition; Tropical fruits; Ultra-performance liquid chromatography; Mass spectrometry.

\section{Resumo}

As características intrínsecas de muitas frutas tropicais causam grandes perdas pós-colheita e impedem sua comercialização como frutas frescas. As informações sobre sua composição são cruciais para definir as condições de processamento e identificar oportunidades de desenvolvimento de produtos. No entanto, os métodos analíticos geralmente usados para quantificar açúcares e ácidos orgânicos são caros e demorados. A análise simultânea por Cromatografia Líquida-Ionização por Electrospray-Espectrometria de Massa (LC-ESI-MS/MS) é uma técnica muito sensível e reproduzível, permitindo a quantificação simultânea precisa em sistemas complexos. Assim, desenvolvemos um método LC-ESI-MS/MS de monitoramento de reações múltiplas (MRM) usando coluna de fase reversa para detectar e quantificar açúcares e alguns ácidos orgânicos em apenas quatro minutos, em frutas selecionadas: araza (Psidium cattleianum), ceriguela (Spondias purpurea), manga (Mangifera indica), goiaba (Psidium guajava) e pitanga (Eugenia uniflora L.). Todas as frutas apresentaram concentrações semelhantes de glicose e frutose, exceto a pitanga, que apresentou valores superiores. O conteúdo de ácidos cítrico, málico e tartárico foi quantificado; algumas frutas se destacaram pelo alto teor de ácidos orgânicos. Os dados gerados sobre a composição das frutas tropicais permitem estabelecer uma correlação entre o teor de carboidratos e as propriedades físicas das polpas das frutas, auxiliando no desenvolvimento de novos produtos.

Palavras-chave: Análise de alimentos; Composição de alimentos; Frutas tropicais; Cromatografia líquida de ultradesempenho; Espectrometria de massa.

\section{Introduction}

Tropical fruits often have unusual but attractive sensory attributes, even as they are an essential source of vitamins in many developing countries (Mertz et al., 2009; Sereno et al., 2018; Tripathi et al., 2011) and their production and commercialization play an important role in providing employment and strengthening the economic prospects of tropical regions (Pingali \& Rosegrant, 1995). The fruit flavor is mostly a balance between the content of sugars and organic acids, responsible for the taste (Medlicott et al., 1990) as well as aromatic volatiles, giving rise to the smell. The characterization of tropical fruits concerning the content of such compounds is crucial for determining critical properties to evaluate the flavor acceptability (Malundo et al., 1996, 2001) and to identify sensorial changes during maturation or processing, as well as being able to define processing conditions for fruits (Elez et al., 2012).

One of the reasons for the limitation of this market is related to the perishability of these fruits, which usually have thin shell, a thin cell wall, combined with high water content and abundance of mono and disaccharides, and other low molecular weight compounds such as organic acids. As a result of the perishability of these fruits, it is estimated that post-harvest losses in tropical regions reach $50 \%$ of agricultural production (Parisi et al., 2012), equivalent to almost 22 million tonnes of food for the year 2013 in Brazil (Santos et al., 2014).

The processing of the fruits allows reducing the waste, increasing its utilization and adding value to the production (Clerici \& Carvalho-Silva 2011). Processing is of particular importance as it allows extending the shelf life of the fruits, which is important, as prices of tropical fruits are highly affected by seasonality. In addition, a better spread of their consumption throughout the year would strengthen the market for tropical fruits. 
Tropical fruits are usually consumed in their natural form or as juices. Processes that are currently employed in Brazil to produce jellies, dehydrated products and ice creams, must be improved before Brazil can compete in the world market. Furthermore, the incentive for the application and development of science and technology to improve processing can positively impact the domestic market, improving the quality of products (Clerici \& Carvalho-Silva, 2011). Many of the tropical and exotic fruits are well characterized in the literature on the centesimal composition as well as on the content of bioactive and volatile compounds (Devalaraja et al., 2011; Damiani et al., 2017; Lopes \& Silva, 2018; Mozarina et al., 2011; Bicas et al., 2011; Dembitsky et al., 2011; Valente et al., 2011; Oliveira et al., 2012; Silva et al., 2012), evidencing their functional and nutritive properties. However, quantitative information on fruit composition, in particular, their content of carbohydrates and organic acids, is crucial for defining processing conditions and identifying product development opportunities.

Despite the importance of the chemical characterization of the fruits (especially regarding sugar and organic acid contents) due to the role of colligative properties in food systems during processing, and the behavior of liquid-solid phase transition in foods rich in low molecular weight compounds, there is no simple, selective and high-throughput analytical method described in the literature for the quantitation of sugars and organic acids. Thus, the simultaneous quantitation of those compounds in complex matrices such as foods becomes a challenge.

The Gas Chromatography-Mass Spectrometry (GC-MS) relies on sample derivatization due to the low volatility of the sugars and organic acids, which usually increases sample preparation time and can reduce the precision and accuracy of the method. On the other hand, the Liquid Chromatography (LC) analysis usually does not require sample derivatization; however, conventional methods are also time-consuming, and are sometimes not selective and sensitive enough.

The typical analytical separation method for the quantitation of organic compounds present in foods is by High Performance Liquid Chromatography (HPLC). However, recent developments in liquid chromatography systems, in particular related to the small size of the particles packed in the column, have given rise to what is known as Ultra-Performance Liquid Chromatography (UPLC). The UPLC allows for the highest resolution, the greatest achievable sensitivity in addition to a reduction in analysis time and savings in solvent consumption (Saidani et al., 2017; Nováková et al., 2006). Given the absence of chromophores for sugars and organic acids, Refractive Index (RI) (Duarte-Delgado et al., 2016; Zaky et al., 2017) and Evaporative Light Scattering (ELS) detectors have been used. Furthermore, Eyéghé-Bickong et al. (2012) reported the use of a HPLC system equipped with a Diode Array Detector (DAD) coupled to a RI detector to simultaneously separate and analyze organic acids and sugars. Organic acids were detected with the DAD at $210 \mathrm{~nm}$, while sugars were detected with the RI. However, DAD detectors present a lack of specificity, and the RI detectors present poor sensitivity and no gradient elution can be used with them, which makes it difficult to analyze sugars and organic acids in complex matrices. Furthermore, despite their overall better sensitivity, ELS detectors also have disadvantages, such as a non-linear response, low reproducibility and moderately low sensitivity to low molecular weight components. Additionally, RI and ELS detectors are also non-specific, which makes it difficult to analyze complex matrices such as fruits. More recently, the use of mass spectrometry in tandem (MS/MS), an extremely sensitive and specific analytical technique capable of providing structural information and quantitative analytical data has been applied for the quantitation of sugars and organic acids in fruits and fruit products (Oliveira et al., 2016).

In relation to the chromatographic separation of polar compounds, column selection is also a critical aspect. Ion exchange and ion-pairing retention are not compatible with MS detection. Hydrophilic Interaction Liquid Chromatographic (HILIC) columns have been successfully used in the chromatographic separation. However, they may present sample and mobile phase solubility problems and long re-equilibration times. Furthermore, the use of conventional reverse phase columns with hydrophobic (non-polar) stationary phase to retain polar analytes is a challenge, since they are poorly retained. 
The aim of this study was to develop an UPLC-ESI-MS/MS method for the simultaneous quantitation of sugar and organic acids in complex systems, such as tropical fruits, in order to reduce the analysis time and to give a more accurate and reliable analytical result. The method was applied to quantify sugars (glucose, fructose and sucrose) and organic acids (citric acid, malic acid and tartaric acid) in selected tropical fruits. To the best of our knowledge, our study is the first that reports on the use of UPLC with reverse phase hydrophobic stationary phase column intended to retain and separate polar organic compounds, for the quantitation of sugars and organic acids in tropical fruits.

\section{Materials and methods}

\subsection{Raw material}

The fresh fruits were obtained from native trees in Campinas, in the state of São Paulo, Brazil, with exception of mango (var. Keitt) and guava (var. Pedro Sato) that were purchased at the central market in Campinas from October 2016 to May 2017. Ciriguela (Spondias purpurea L.) (Figure 1B) and mango (Mangifera indica L.) (Figure 1D) from Anacardiaceae family and araza (Psidium cattleianum L.) (Figure 1A), guava (Psidium guajava L.) (Figure 1D) and pitanga (Eugenia uniflora L.) (Figure 1C) from Myrtaceae family were chosen based on an analysis of commercial production as well as lack of information in the literature about their composition and physical properties.

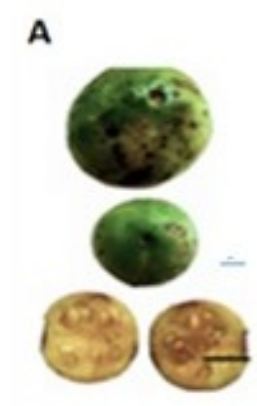

B

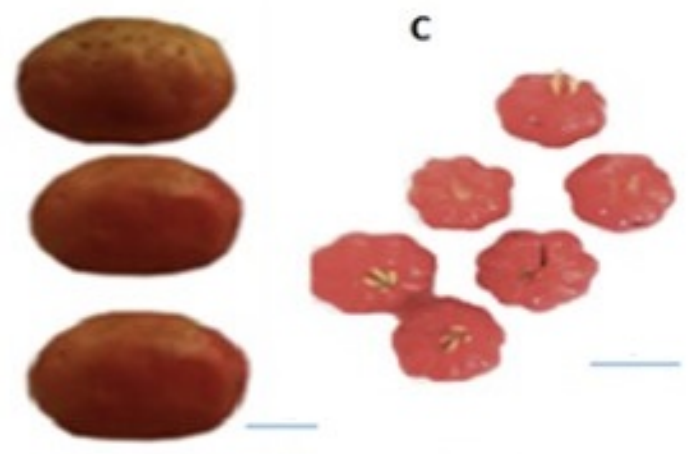

D

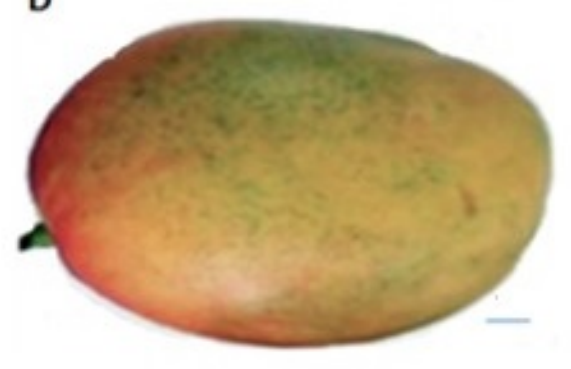

$\mathbf{E}$

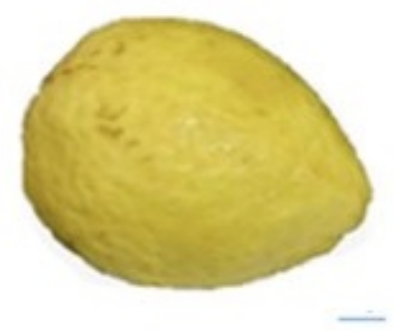

Figure 1. Tropical Fruits: (A) Araza; (B) Ciriguela; (C) Pitanga; (D) Mango; (E) Guava. Bars represent $1 \mathrm{~cm}$.

\subsection{Fruit pulp processing}

The fruits were visually inspected regarding the absence of lesions, color, and an adequate state of ripeness for consumption. Immediately after they were collected, the samples were washed by immersion in sodium hypochlorite solution $(10 \mathrm{mg} / \mathrm{L})$ and then rinsed in potable water. The weight of fruit that was used to prepare the pulp was 20,15,5, 10 and $10 \mathrm{~kg}$ for araza, ciriguela, pitanga, mango and guava, respectively. This amount 
of pulp represent a $n$ of approximately 25 fruits for mango and guava, and $n$ of approximately 100 fruits for araza, ciriguela and pitanga. The pulp was obtained through the use of sieves, separating the pulp from the skin. No water was added. The pulp was packed in glass trays equipped with a lid $(10 \mathrm{~cm}$ diameter), with a fill height of approximately $5 \mathrm{~mm}$. Samples were immediately frozen and stored at $-18{ }^{\circ} \mathrm{C}$ until they could be lyophilized.

\subsection{Freeze drying}

The trays containing the frozen pulp were transferred to the drying chamber of a lyophilizer (LH 2000TT, Terroni, Brazil). The samples were freeze-dried for $48 \mathrm{~h}$ at $-48{ }^{\circ} \mathrm{C}$ at a pressure of $1.33 \mathrm{~Pa}$. The dried material was ground and kept at room temperature in desiccators containing silica gel. The moisture content of the powder was determined after freeze-drying in an oven at $100^{\circ} \mathrm{C}$ and was expressed on wet basis. The original color was largely retained after freeze-drying (Figure 2).

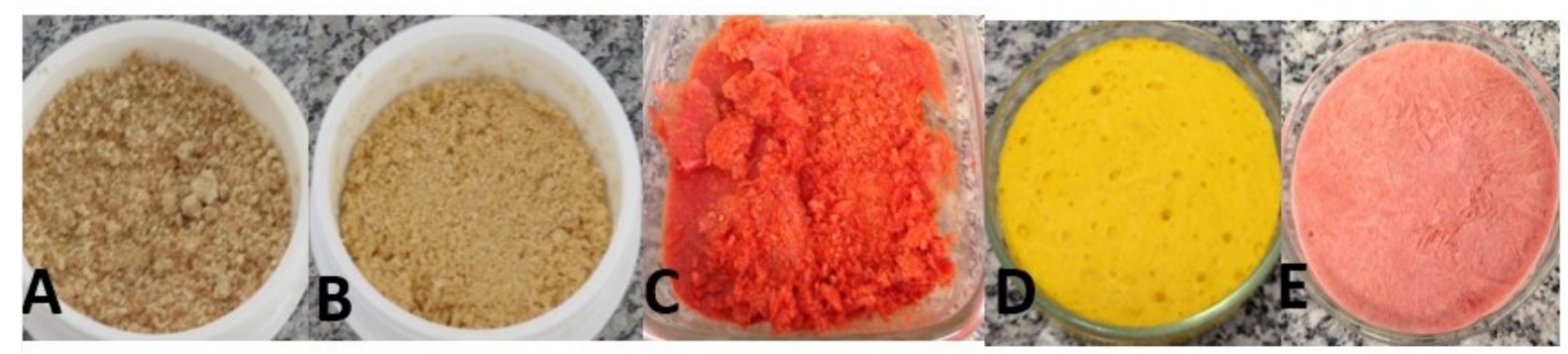

Figure 2. Freeze-dried tropical fruits: (A) Araza; (B) Ciriguela; (C) Pitanga; (D) Mango; (E) Guava. The colors of the freeze-dried samples are visually close to the original fruits.

\subsection{Analytical standards and solvents}

Tartaric, citric and malic acids were selected as standards for the quantitative analysis of the organic acids. This selection was based on a previous revision from the literature indicating that they are present in most fruits. The carbohydrate standards used were $\mathrm{d}(+)$ sucrose, $\mathrm{d}(+)$ glucose, $\mathrm{d}(-)$ fructose. All standards had purity higher than $98 \%$ and were obtained from Labsynth (Diadema, SP, Brazil). Acetonitrile and formic acid (FA) HPLC grade were purchased from Merck (Hohenbrunn, Germany). All other solvents were purchased from Fisher Scientific (Hampton, New Hampshire, USA) and were of the highest purity available. Ultra-pure deionized water was obtained using a Milli-Q water purifier system, Simplicity model (Millipore, Bedford, MA, USA).

\subsection{Stock standard solutions, analytical curves and sample preparation}

Stock solutions of each analytical standard was prepared in ultrapure deionized water at a concentration of $1000 \mathrm{mg} / \mathrm{L}$. A 6-point $(0.2,0.5,1.0,2.0,5.0$ and $10.0 \mathrm{mg} / \mathrm{L})$ analytical curve of each standard was prepared by diluting the stock solution with ultrapure deionized water. Freeze-dried tropical fruits samples were also properly diluted with ultrapure deionized water in order the concentration of the target analyzed compounds (sugars and organic acids) was within the range of their respective analytical curve. The diluted samples (dilution factor ranged between 10-400 times) were subjected to an ultrasonic bath for $10 \mathrm{~min}$ and centrifuged for $5 \mathrm{~min}$ at $10,000 \mathrm{x} g$ before injection into the UHPLC-ESI-MS/MS system. 


\subsection{Instrumental and analytical conditions}

The analysis were carried out using an UPLC system (Waters Xevo I-Class, Milford, USA) coupled to a tandem mass spectrometry detector (Waters Xevo TQD, Milford, USA) equipped with an ESI operated in negative mode (UPLC-ESI-MS/MS). Separation was carried out using an ACQUITY UPLC $®$ HSS T3

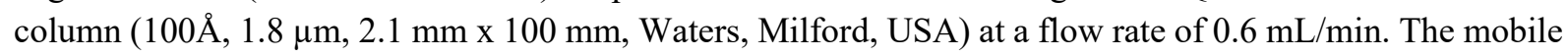
phase was composed of solvent A $(0.1 \%$ formic acid in water) and solvent $\mathrm{B}(0.1 \%$ formic acid in acetonitrile). The linear gradient was from 0 to $90 \%$ of solvent B over 4 min and the column oven was kept at $35{ }^{\circ} \mathrm{C}$. The instrument control and data processing were performed by MassLynx software (Waters Co.) version 4.1. Samples were analyzed in Multiple Reaction Monitoring (MRM) mode, in which the precursor ion is specified for MS/MS fragmentation and then monitored for a fragment ion (Table 1). For the MS operating conditions, the following parameters were set: capillary voltage $0.5 \mathrm{kV}$, source temperature at $150{ }^{\circ} \mathrm{C}$, desolvation temperature at $350{ }^{\circ} \mathrm{C}$, cone gas flow $20 \mathrm{~L} / \mathrm{h}$ and desolvation gas flow $900 \mathrm{~L} / \mathrm{h}$. All sample solutions were prepared and analyzed in triplicate.

Table 1. Multiple Reaction Monitoring (MRM) transitions ${ }^{1}$ used in the sugar and organic acid assignments.

\begin{tabular}{|c|c|c|c|}
\hline Compound & MRM transitions & Cone Voltage (V) & Collision Energy (V) \\
\hline \multirow{2}{*}{ Citric Acid } & $190.9>86.9$ & \multirow{2}{*}{25} & 18 \\
\hline & $190.9>110.9$ & & 12 \\
\hline \multirow{2}{*}{ Malic Acid } & $133.0>70.9$ & \multirow{2}{*}{25} & 15 \\
\hline & $133.0>115$ & & 10 \\
\hline \multirow{2}{*}{ Tartaric Acid } & $148.9>72.9$ & \multirow{2}{*}{25} & 15 \\
\hline & $148.9>86.9$ & & 15 \\
\hline \multirow{2}{*}{ Fructose } & $179.0>58.9$ & \multirow{2}{*}{15} & 20 \\
\hline & $179.0>88.9$ & & 10 \\
\hline \multirow{2}{*}{ Glucose } & $179.0>58.9$ & \multirow{2}{*}{15} & 18 \\
\hline & $179.0>88.9$ & & 8 \\
\hline \multirow{2}{*}{ Sucrose } & $341.1>88.9$ & \multirow{2}{*}{30} & 25 \\
\hline & $341.1>179.0$ & & 15 \\
\hline
\end{tabular}

${ }^{1}$ Quantitation transitions are shown in bold numbers.

Sugars and organic acids in the samples were identified by comparison of their UPLC-ESI-MS/MS dissociation patterns and retention time with those of the standards. The analytes were quantitated in the diluted samples by comparison with the analytical curve constructed for each standard.

\subsection{Method validation}

The validation of the analytical method was performed following the recommendations of the guide for the validation of analytical methods provided by Agência Nacional de Vigilância Sanitária (ANVISA) (Brasil, 2017). The following validation parameters of the method were determined as following: linearity and linear range, sensitivity, selectivity (assessed by the sample dilution approach), precision (intra-day and inter-day assays), accuracy and Limit of Quantitation (LoQ). The linearity, linear range, sensitivity and LoQ were established through the analytical curve obtained by triplicate analysis of the target analytes (sugars and organic acids) in solvent. 


\section{Results and discussion}

Aiming at reducing sample analysis time (including both sample preparation and chromatographic analysis), an analytical method based on UPLC-ESI-MS/MS was developed. By using columns packed with sub-2 $\mu \mathrm{m}$ particles, the method is expected to be both faster and more sensitive, as analytes are concentrated on a narrower chromatographic band.

The sample preparation (extraction of the analytes and cleanup of the extract) reported in this study can be considered a high-throughput step, as it consists only in the extraction of the analytes with water, dilution and centrifugation of the extracts before injection in the UPLC-ESI-MS/MS system. Besides, coupling UPLC with tandem quadrupole mass spectrometry (UPLC-ESI-MS/MS) further improves the selectivity that is needed to analyze specific molecules in complex matrices such as fruit pulps in shorter times.

Due to their highly polar character, conventional reversed-phase LC columns are not appropriate for sugars and organic acids, as usually not retention is observed whatsoever. This implies the use of Hydrophilic Interaction Liquid Chromatography (HILIC), an HPLC technique to separate compounds from these classes of polar molecules. However, HILIC columns tend to take a longer time for re-equilibration after being subjected to chromatographic gradients, which results in either longer analysis times or in lack of reproducibility. In an attempt to unite the advantages of reversed-phase chromatography (i.e. quicker re-equilibration times) with that of HILIC (retention of very polar organic compounds), the proposed method was developed using an Acquity HSS T3 column. This column consists of a reverse phase C18 column, with an end-capping that allows the retention of very polar compounds. A typical chromatogram of sugars and organic acids is shown in Figure 3, from which it can be observed that the proposed method provides a short time of analysis.

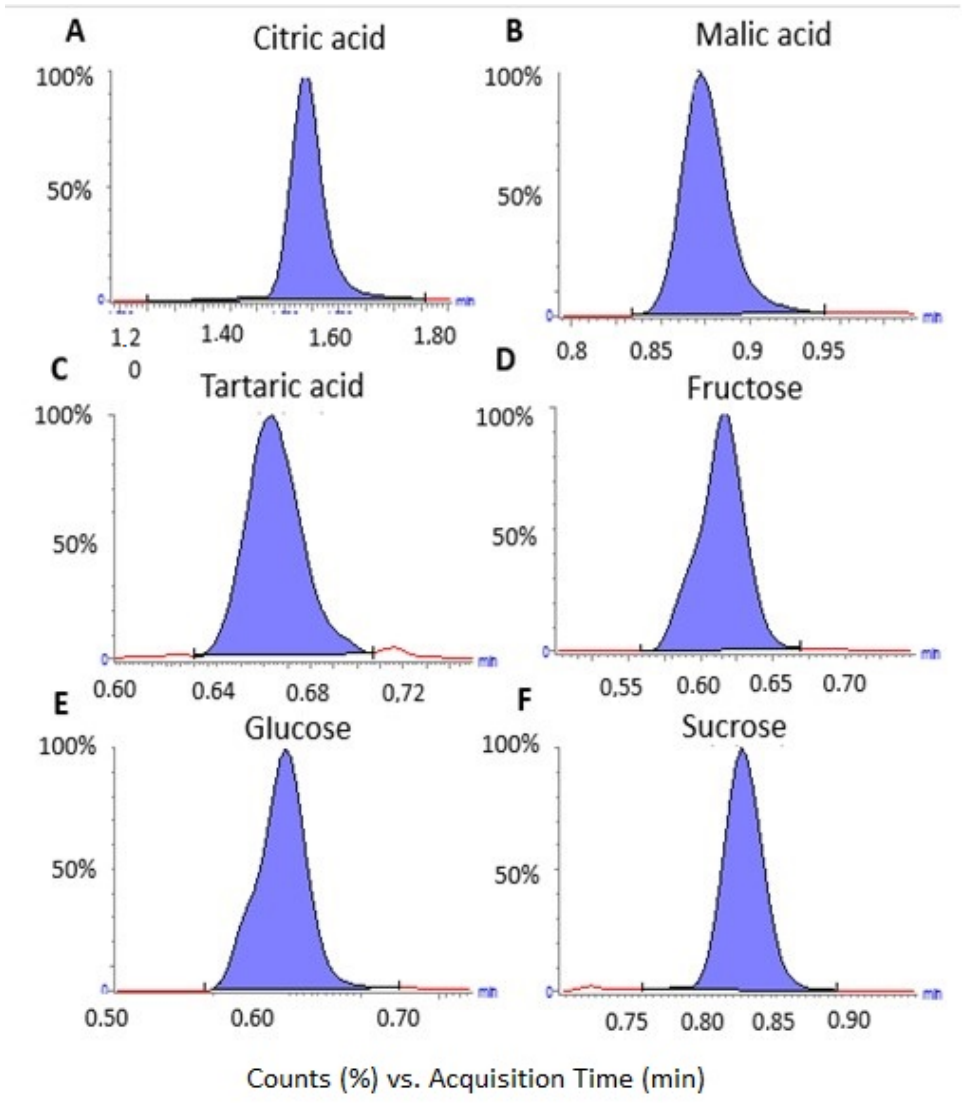

Figure 3. Chromatograms obtained for araza: (A) Citric Acid; (B) Malic Acid; (C) Tartaric Acid; (D) Fructose; (E) Glucose; (F) Sucrose. 
It should be noted that for the validation of the method in the present study there is no blank matrix (matrix free of target analytes), that can be used in the evaluation of selectivity by conventional procedures. However, Brasil (2017) establishes that the use of alternative approaches for the validation of analytical methods applied to biological products will be admitted and that the use of a method with technical limitations to determine selectivity is accepted through technical justification. In this regard, Bernardi et al., (2016); Yang et al., 2015) demonstrated that the sample dilution (dilution factor 15 to 100) before injection into the LC-ESI MS/MS system is an easy and effective method to improve the selectivity of the method and to reduce or eliminate the matrix effect (effect on the analytical response induced by interfering compounds present in the matrix) (Bernardi et al., 2016). Thus, in this study, selectivity and elimination of the possible matrix effect was assessed by the dilution approach, since depending on the matrix and the analyte the samples were diluted (ranged between 10 to 400 times) to get in the linear range of the analytical curves. In addition, matrix-matched analytical curves were constructed using the freeze-dried material of each fruit. These curves were compared with analytical curves in solvent to assess the matrix effect by comparing the sensitivity of both analytical curves. No matrix effect was observed corroborating the dilution approach consequent to the high dilution factor performed with the freeze-dried material of each fruit. Thus, the quantitation of the target analytes was made by external calibration curves.

To evaluate the linearity, analytical curves were constructed with 6 levels of concentration (between 0.2 and $10.0 \mathrm{mg} / \mathrm{L}$ ) in triplicate. The calibration was performed by linear regression of the peak-area of the analyte versus the concentration of the analyte. Linearity and sensitivity were expressed as the linear correlation coefficient $\left(r^{2}\right)$ and the slope of the analytical curve, respectively. All sugars and organic acids showed $r^{2}$ values above 0.986 , demonstrating a strong correlation between the target analytes concentration level and the analytical response. The analytical responses were evaluated according to the Grubbs test $(p=0.05)$ to verify outlier values, and Cochran test $(p=0.05)$ to check the homoscedasticity of the values. For all analytes, homogeneous variances were verified. Range and equation of the analytical curves, and linearity are shown in Table 2.

Table 2. Range and equation of the analytical curves, and linearity expressed by the coefficient of determination $\left(r^{2}\right)$.

\begin{tabular}{cccc}
\hline Compounds & Range $(\mathbf{m g} / \mathbf{L})$ & Equation of the analytical curve & Linearity $\left(\boldsymbol{r}^{\mathbf{2}}\right)$ \\
\hline Citric Acid & $0.2-10$ & $\mathrm{y}=1701.68 \mathrm{x}-304.761$ & 0.986 \\
\hline Malic Acid & $0.2-10$ & $\mathrm{y}=1650.2 \mathrm{x}-8.0007$ & 0.989 \\
\hline Tartaric Acid & $0.2-10$ & $\mathrm{y}=411.756-46.6786$ & 0.995 \\
\hline Fructose & $0.2-10$ & $\mathrm{y}=233.149 \mathrm{x}+12.1227$ & 0.994 \\
\hline Glucose & $0.2-10$ & $\mathrm{y}=273.365 \mathrm{x}+11.0267$ & 0.992 \\
\hline Sucrose & $0.2-10$ & $\mathrm{y}=240.847 \mathrm{x}+23.2101$ & 0.986 \\
\hline
\end{tabular}

The intra-day precision of the method, expressed as the Relative Standard Deviation (RSD) of peak area measurements $(n=6)$, was evaluated by adding known quantities of the target analytical standards to the fruit extracts before dilution. The results were obtained with the method operating over one day under the same conditions, using the fruit extracts spiked with the standards of the target compounds at concentration levels of $0.5 ; 2.0$ and $10 \mathrm{mg} / \mathrm{L}$. The inter-day precision was determined under the same conditions as the intra-day precision; however, the analyzes were performed for 3 consecutive days. According to ANVISA, the RSD value obtained was lower than $15 \%$ (Table 3 ).

The accuracy of the method was determined under the same conditions as intra-day precision and the results expressed as a percent of recovery. Brasil (2017) recommends a recovery in the range of $80-110 \%$ of the target concentration (Table 3). The LoQ was established through the analytical curves in solvent, and was considered to be the first point of the analytical. All of them showed a signal-to-noise ratio above 10 and an RSD lower than $20 \%$ (Table 3 ). 
Development and application of a liquid chromatography-mass spectrometry method for the determination of sugars and organics acids in araza, ceriguela, guava, mango and pitanga

Cardoso, P. C. et al.

Table 3. Precision ${ }^{1}$ (intra-day and inter-day), accuracy ${ }^{1}$ and limit of quantitation (LoQ) of the UPLC ESI-MS/MS analytical method for quantitation of sugars and organic acids in selected tropical fruits.

\begin{tabular}{cccc}
\hline Compounds & Range of precision $(\mathbf{C V} \%)^{\mathbf{2}}$ & Range of accuracy $\%$ & LoQ $(\mathbf{m g} / \mathbf{g}$ fruits) \\
\hline Citric Acid & $1.20-5.28$ & $-12.60-14.00$ & \\
\cline { 1 - 3 } Malic Acid & $1.29-9.23$ & $-9.67-11.87$ & \multirow{2}{*}{0.02} \\
\hline Tartaric Acid & $0.59-10.19$ & $-14.33-13.33$ & \\
\hline Fructose & $2.37-14.67$ & $-13.67-8.00$ & \\
\hline Glucose & $2.34-13.18$ & $-8.00-8.00$ \\
\hline Sucrose & $2.82-13.67$ & $-11.00-13.98$ \\
\hline
\end{tabular}

${ }^{1}$ Range of precision (intra-day and inter-day) and accuracy data are related to analytical curve concentration levels of $0.5 ; 2.0$ and $10 \mathrm{mg} / \mathrm{L}$; ${ }^{2} \mathrm{CV}=$ coefficient of variation.

From the results obtained (Table 4), we could distinguish three groups of fruits in relation to their total sugar content. Araza and pitanga showed the lowest total sugar content $(\sim 30 \mathrm{mg} / \mathrm{g})$, ciriguela and guava had an intermediary value $(\sim 50 \mathrm{mg} / \mathrm{g})$ and mango $(87 \mathrm{mg} / \mathrm{g})$ had the highest total sugar content. In line with the low total sugar content, araza and pitanga also showed very low sucrose levels $(1.05 \mathrm{mg} / \mathrm{g})$, and mango was maintained in the upper range, with $64.54 \mathrm{mg} / \mathrm{g}$. The high sugar content of mangoes can be understood as they, like bananas, contain a high amount of starch in the unripe stage. During ripening, starch is then hydrolyzed into simple sugars (Medlicott et al., 1988; Selvaraj et al., 1989), which, in turn, is in part converted into sucrose. In relative terms, guava showed a similar behavior as araza, with a sucrose content of about $3-5 \%$ of the total sugar. However, besides not being high the level of starch in pitanga, the fruit presented $12.38 \mathrm{mg} / \mathrm{g}$ of sucrose, which represents $24.22 \%$ of its total sugar content.

Table 4. Sugar content of selected tropical fruits.

\begin{tabular}{ccccc}
\hline \multirow{2}{*}{ Fruit } & \multicolumn{4}{c}{ Sugar content $(\mathbf{m g} / \mathbf{g})$} \\
\cline { 2 - 5 } & Sucrose & Glucose & Fructose & Total Sugars \\
\hline Araza & 1.05 & 14.49 & 14.34 & 29.88 \\
\hline Ciriguela & 12.38 & 19.56 & 19.16 & 51.10 \\
\hline Guava & 2.79 & 27.09 & 27.09 & 56.97 \\
\hline Pitanga & NA & 28.00 & 3.60 & 31.60 \\
\hline Mango & 64.54 & 9.96 & 9.96 & 84.46 \\
\hline
\end{tabular}

While the individual sugar profiles depend on the cultivar, stage of ripeness, postharvest treatment and storage conditions (United States Department of Agriculture, 2018), we could conclude that the values found in this work are generally consistent with the literature (Damiani et al., 2017; El Bulk et al., 1997; Kozioł \& Macía, 1998; Lopes et al., 2005; Medlicott et al., 1988; United States Department of Agriculture, 2018; Rojas-Garbanzo et al., 2017; Wilson et al., 1982).

The guava that has been analyzed presented $56.97 \mathrm{mg} / \mathrm{g}$ of total sugar. Values for unspecified species of guava of $89.2 \mathrm{mg} / \mathrm{g}$ of total sugar were also reported (United States Department of Agriculture, 2018; RojasGarbanzo et al., 2017). In addition, fructose was found to be the predominant sugar in ripe guava, followed by glucose and sucrose. It has been reported (Maldonado-Celis et al., 2019; El Bulk et al., 1997; Medlicott et al., 1988; Wilson et al., 1982) that, for 'Keitt' mangoes, sucrose contributes $57 \%$ of the total sugar content followed by the reducing sugars fructose $(28 \%)$ and glucose $(15 \%)$. We analyzed the same mango variety, but for our sample the sucrose level made up $76.4 \%$ of total sugar, and fructose and glucose totaled only $23.6 \%$ in almost equal parts.

On the other hand, the very rare references available on the composition of ciriguela showed important differences between the ratio of sugars. Some authors reported higher amounts of sucrose than glucose and 
fructose than we detected (about three times more: $2 \%$ glucose, $2.53 \%$ fructose and $6.59 \%$ sucrose) (Kozioł \& Macía, 1998). In our study, the concentration of soluble sugars in ciriguela corresponded to $51.10 \mathrm{mg} / \mathrm{g}$ of which approximately $24 \%$ was sucrose, $38 \%$ fructose and $37 \%$ glucose.

The balance between glucose and fructose was similar for all fruits, with the exception of pitanga that showed higher values for glucose $(\sim 28 \mathrm{mg} / \mathrm{g})$ than for fructose $(3.60 \mathrm{mg} / \mathrm{g})$. No sucrose was detected in pitanga and its total sugar content $(31.60 \mathrm{mg} / \mathrm{g})$ was inferior to the values reported in the literature (around $115 \mathrm{mg} / \mathrm{g}$ ) (Franzon et al., 2018; Lopes et al., 2005; Santos et al., 2002). The total sugar content for araza $(29.88 \mathrm{mg} / \mathrm{g}$ ) was also much lower than reported in the literature, $167 \mathrm{mg} / \mathrm{g}$ (Damiani et al., 2017).

Many fruits are characterized by the total acidity, which is linked to the content of the organic acids. Araza presented a high acidity, in line with its characteristic acidic flavor. The literature provided some data on the acidity of the fruits, which we could rank from the lowest to the highest acidic content: araza $(0.52 \%)$ (Damiani et al., 2017), ciriguela (0.73\%) (Kozioł \& Macía 1998) and pitanga (1.24\%) (Lopes et al., 2005). For our analyses, we looked at several individual organic acids, namely citric, malic and tartaric acid. These were chosen because they are most commonly present in fruits. The first analysis of our results revealed that some fruits stood out by their high content of organic acids: araza was the richest in citric acid $(6.7 \mathrm{mg} / \mathrm{g})$ and pitanga in malic acid $(21.6 \mathrm{mg} / \mathrm{g})$.

An interesting difference between our results and literature data was observed for araza (Hernández et al., 2007; Lopes \& Silva, 2018). Whereas for our samples, citric acid is determined to be the main organic acid and only a low content of malic acid was found, Hernández et al. (2007) determined malic acid to be the dominant organic acid and only a low amount of citric acid was detected. This is an important observation that could be related to differences in araza variety or to differences in ripeness (Hernández et al., 2007). As no further studies on the organic acid composition of araza are available, further studies would need to be carried out.

The predominant acids in Keitt mango were citric acid $(1.59 \mathrm{mg} / \mathrm{g})$ and malic acid $(0.34 \mathrm{mg} / \mathrm{g})$, corroborating the studies done by Medlicott et al. (1990). However, contrary to their results, tartaric acid was not detected in our study. Ciriguela showed malic acid as the predominant organic acid, followed by citric and tartaric acids. While the ranking of these organic acids is in accordance with the results reported by Kozioł \& Macía (1998), the amounts we detected were lower (Table 5). We determined $0.54 \mathrm{mg} / \mathrm{g}, 0.08 \mathrm{mg} / \mathrm{g}$ and $0.03 \mathrm{mg} / \mathrm{g}$ for malic, citric and tartaric acids, which should be compared to $1.10 \mathrm{mg} / \mathrm{g}, 0.3 \mathrm{mg} / \mathrm{g}$ and $0.2 \mathrm{mg} / \mathrm{g}$, respectively, reported by Kozioł \& Macía (1998).

Finally, guava showed citric acid as the major organic acid, followed by malic and tartaric acids (Table 5).

Table 5. Organic acid quantitation for selected tropical fruits.

\begin{tabular}{ccccc}
\hline \multirow{2}{*}{ Fruit } & \multicolumn{4}{c}{ Organic acid content $\mathbf{( m g / g )}$} \\
\cline { 2 - 5 } & Citric acid & Malic acid & Tartaric acid & Total organic acids \\
\hline Ciriguela & 0.08 & 0.54 & 0.03 & 0.65 \\
\hline Mango & 1.59 & 0.34 & 0.00 & 1.94 \\
\hline Guava & 1.59 & 1.20 & 0.03 & 2.82 \\
\hline Araza & 6.57 & 0.38 & 0.01 & 6.96 \\
\hline Pitanga & 6.70 & 21.60 & 0.11 & 28.41 \\
\hline
\end{tabular}

\section{Conclusions}

We have developed and validated an UPLC-ESI-MS/MS multiple reaction monitoring (MRM) method for the simultaneous determination of sugars and organic acids in tropical fruits, and have successfully applied this method to quantify the saccharides glucose, fructose and sucrose and the organic acids, citric 
acid, malic acid and tartaric acid in selected tropical fruits. The method showed good linearity and selectivity, in addition to satisfactory recovery, precision and limit of quantitation. Hence, it permitted a short period of sample preparation and a reduced chromatographic analysis time by using a silica-based bonded phase chromatography column. The tropical fruits were selected on basis of their potential importance for Brazilian regional development. The newly generated data on the composition of tropical fruits will be used to establish a correlation between carbohydrate and organic acids content and the physical properties of the fruit pulps, assisting in a rapid response to product and process development.

\section{Acknowledgements}

Authors wish to thank Apex Science Consultoria Analitica Ltda, for the UPLC-ESI-MS/MS analyses and Laboratory of Food Innovation of Universidade Estadual de Campinas (Unicamp) for all the analytical support. This study was financed in part by the Coordenação de Aperfeiçoamento de Pessoal de Nivel Superior (CAPES - Finance Code 001), and by the São Paulo Research Foundation (FAPESP, Process 2018/194410), Brazil.

\section{References}

Bernardi, G., Rizzetti, T., Adaime, M., Zanella, R., \& Prestes, O. (2016). Fast sample preparation method using ultra-high performance liquid chromatography coupled to tandem mass spectrometry for natamycin determination in wine samples. Journal of the Brazilian Chemical Society, http://dx.doi.org/10.21577/0103-5053.20160235

Bicas, J. L., Molina, G., Dionísio, A. P., Barros, F. F. C., Wagner, R., Maróstica Junior, M. R., \& Pastore, G. M. (2011). Volatile constituents of exotic fruits from Brazil. Food Research International, 44(7), 1843-1855.

http://dx.doi.org/10.1016/j.foodres.2011.01.012

Brasil. Agência Nacional de Vigilância Sanitária - ANVISA. (2017, july 25). Dispõe sobre a validação de métodos analíticos e dá outras providências (Diretoria Colegiada Resolução RDC n 166, de 24 de julho de 2017). Diário Oficial [da] República Federativa do Brasil (No. 141, pp. 87-89). Brasília, seção 1. Retrieved in 2020, July 8, from https://www.in.gov.br/materia/lasset_publisher/Kujrw0TZC2Mb/content/id/19194581/do1-2017-07-25-resolucao-rdc-n-166-de-24-de-julho-de-2017-19194412

Clerici, M. T. P. S., \& Carvalho-Silva, L. B. (2011). Nutritional bioactive compounds and technological aspects of minor fruits grown in Brazil. Food Research International, 44(7), 1658-1670. http://dx.doi.org/10.1016/j.foodres.2011.04.020

Damiani, T. F., Pereira, L. P., \& Ferreira, M. G. (2017). Consumo de frutas, legumes e verduras na Região Centro-Oeste do Brasil: prevalência e fatores associados. Ciência \& Saúde Coletiva, 22(2), 369-382. http://dx.doi.org/10.1590/141381232017222.12202015

Dembitsky, V. M., Poovarodom, S., Leontowicz, H., Leontowicz, M., Vearasilp, S., Trakhtenberg, S., \& Gorinstein, S. (2011). The multiple nutrition properties of some exotic fruits: biological activity and active metabolites. Food Research International, 44(7), 1671-1701. http://dx.doi.org/10.1016/j.foodres.2011.03.003

Devalaraja, S., Jain, S., \& Yadav, H. (2011). Exotic fruits as therapeutic complements for diabetes, obesity and metabolic syndrome. Food Research International, 44(7), 1856-1865. PMid:21857774. http://dx.doi.org/10.1016/j.foodres.2011.04.008

Duarte-Delgado, D., Ñústez-López, C.-E., Narváez-Cuenca, C.-E., Restrepo-Sánchez, L.-P., Melo, S. E., Sarmiento, F., Kushalappa, A. C., \& Mosquera-Vásquez, T. (2016). Natural variation of sucrose, glucose and fructose contents in Colombian genotypes of Solanum tuberosum Group Phureja at harvest. Journal of the Science of Food and Agriculture, 96(12), $4288-4294$. PMid:27133474. http://dx.doi.org/10.1002/jsfa.7783

El Bulk, R. E., Babiker, E. F. E., \& El Tinay, A. H. (1997). Changes in chemical composition of guava fruits during development and ripening. Food Chemistry, 59(3), 395-399. http://dx.doi.org/10.1016/S0308-8146(96)00271-3

Elez, P., Soliva, R., \& Mart, O. (2012). Novel Thermal and Non-Thermal Technologies for Fluid Foods. Academic Press.

Eyéghé-Bickong, H. A., Alexandersson, E. O., Gouws, L. M., Young, P. R., \& Vivier, M. A. (2012). Optimisation of an HPLC method for the simultaneous quantification of the major sugars and organic acids in grapevine berries. Journal of Chromatography. B, Analytical Technologies in the Biomedical and Life Sciences, 885-886, 43-49. PMid:22265666. http://dx.doi.org/10.1016/j.jchromb.2011.12.011

Franzon, R. C., Carpenedo, S., Viñoly, M. D., \& Raseira, M. C. B. (2018). Pitanga: Eugenia uniflora L. In S. Rodrigues, E. O. Silva \& E. S. Brito (Eds.), Exotic fruits: Reference guide (pp. 333-338). Saint Louis: Elsevier. https://doi.org/10.1016/B978-0-12803138-4.00044-7

Hernández, M. S., Martínez, O., \& Fernández-Trujillo, J. P. (2007). Behavior of arazá (Eugenia stipulate) fruit quality traits during growth, development and ripening. Scientia Horticulturae, 111(3), 220-227. http://dx.doi.org/10.1016/j.scienta.2006.10.029

Kozioł, M. J., \& Macía, M. J. (1998). Chemical composition, nutritional evaluation, and economic prospects of Spondias purpurea (Anacardiaceae). Economic Botany, 52(4), 373-380. http://dx.doi.org/10.1007/BF02862067 
Development and application of a liquid chromatography-mass spectrometry method for the determination of sugars and organics acids in araza, ceriguela, guava, mango and pitanga

Cardoso, P. C. et al.

Lopes, A. S., Mattietto, R. A., \& Menezes, H. C. (2005). Estabilidade da polpa de pitanga sob congelamento. Food Science and Technology, 25(3), 553-559. http://dx.doi.org/10.1590/S0101-20612005000300026

Lopes, M. M. A., \& Silva, E. O. (2018). Araça: Psidium cattleyanum Sabine. In S. Rodrigues, E. O. Silva \& E. S. Brito (Eds.), Exotic fruits: Reference guide (pp. 31-36). Saint Louis: Elsevier. https://doi.org/10.1016/B978-0-12-803138-4.00007-1

Maldonado-Celis, M. E., Yahia, E. M., Bedoya, R., Landázuri, P., Loango, N., Aguillón, J., Restrepo, B., \& Guerrero Ospina, J. C. (2019). Chemical composition of mango (Mangifera indica L.) fruit: nutritional and phytochemical compounds. Frontiers in Plant Science, 10, 1073. PMid:31681339. http://dx.doi.org/10.3389/fpls.2019.01073

Malundo, T. M. M., Baldwin, E. A., Ware, G. O., \& Shewfelt, R. L. (1996). Volatile composition and interaction influence flavor properties of mango (Mangifera indica I.). Proceedings of the Annual Meeting of the Florida State Horticultural Society, 109, 264-268. https://fshs.org/proceedings-o/1996-vol-109/264-268 (MALUNDO).pdf

Malundo, T. M. M., Shewfelt, R. L., Ware, G. O., \& Baldwin, E. A. (2001). Sugars and acids influence flavor properties of mango (Mangifera indica). Journal of the American Society for Horticultural Science, 126(1), 115-121. http://dx.doi.org/10.21273/JASHS.126.1.115

Medlicott, A. P., Sigrist, J. M. M. S., \& Sy, O. (1990). Ripening of mangoes following low-temperature storage. American Society for Horticultural Science Journal, 115(3), 430-434. http://dx.doi.org/10.21273/JASHS.115.3.430

Medlicott, A. S., Reynolds, A. P., Reynolds, S. B., Polytechnic, S. B., New, S. W., \& Thompson, A. K. (1988). Harvest maturity effects on mango fruit ripening. Tropical Agriculturist, 65, 153-157.

Mertz, C., Gancel, A.-L., Gunata, Z., Alter, P., Dhuique-Mayer, C., Vaillant, F., Perez, A. M., Ruales, J., \& Brat, P. (2009). Phenolic compounds, carotenoids and antioxidant activity of three tropical fruits. Journal of Food Composition and Analysis, 22(5), 381-387. http://dx.doi.org/10.1016/j.jfca.2008.06.008

Mozarina, M., Almeida, B., Henrique, P., Sousa, M., Martha, Â., Arriaga, C., Matias, G., Emanuel, C., Magalhães, D. C., Arraes G., Leda, T., \& Lemos, G. (2011). Bioactive compounds and antioxidant activity of fresh exotic fruits from northeastern Brazil. Food Research International, 44(7), 2155-2159. http://dx.doi.org/10.1016/j.foodres.2011.03.051

Nováková, L., Solichová, D., \& Solich, P. (2006). Advantages of ultra performance liquid chromatography over highperformance liquid chromatography: Comparison of different analytical approaches during analysis of diclofenac gel. Journal of Separation Science, 29(16), 2433-2443. PMid:17154123. http://dx.doi.org/10.1002/jssc.200600147

Oliveira, B. G., Costa, H. B., Ventura, J. A., Kondratyuk, T. P., Barroso, M. E. S., Correia, R. M., Pimentel, E. F., Pinto, F. E., Endringer, D. C., \& Romão, W. (2016). Chemical profile of mango (Mangifera indica L.) using electrospray ionisation mass spectrometry (ESI-MS). Food Chemistry, 204, 37-45. PMid:26988473. http://dx.doi.org/10.1016/j.foodchem.2016.02.117

Oliveira, V. B., Yamada, L. T., Fagg, C. W., \& Brandão, M. G. L. (2012). Native foods from Brazilian biodiversity as a source of bioactive compounds. Food Research International, 48(1), 170-179. http://dx.doi.org/10.1016/j.foodres.2012.03.011

Parisi, M. C. M., Henrique, C. M., \& Prati, P. (2012). Perdas pós-colheita: um gargalo na produção de alimentos. Pesquisa \& Tecnologia, 9(2), 1-5.

Pingali, P. L., \& Rosegrant, M. W. (1995). Agricultural commercialization and diversification: Processes and policies. Food Policy, 20(3), 171-185. http://dx.doi.org/10.1016/0306-9192(95)00012-4

Rojas-Garbanzo, C., Zimmermann, B. F., Schulze-Kaysers, N., \& Schieber, A. (2017). Characterization of phenolic and other polar compounds in peel and flesh of pink guava (Psidium guajava L. cv. 'Criolla') by ultra-high performance liquid chromatography with diode array and mass spectrometric detection. Food Research International, 100(Pt 3), 445-453. PMid:28964367. http://dx.doi.org/10.1016/j.foodres.2016.12.004

Saidani, F., Giménez, R., Aubert, C., Chalot, G., Betrán, J. A., \& Gogorcena, Y. (2017). Phenolic, sugar and acid profiles and the antioxidant composition in the peel and pulp of peach fruits. Journal of Food Composition and Analysis, 62, 126-133. http://dx.doi.org/10.1016/j.jfca.2017.04.015

Santos, A. F., Silva, S. de M., Mendonça, R. M. N., Silva, M. S., Alves, R. E., \& Filgueiras, H. A. C. (2002). Alterações fisiológicas durante a maturação de pitanga (Eugenia uniflora L.). Proceedings of the Interamerican Society for Tropical Horticulture, 46, 52-54

Santos, C. E., Kist, B. B., Carvalho, C., Reetz, E. R., \& Drum, M. (2014). Anuário brasileiro de fruticultura. Santa Cruz do Sul: Editora Gazeta. Retrieved in 2020, July 8, from http://www.editoragazeta.com.br/produto/anuario-brasileiro-da-fruticultura-2014/

Selvaraj, Y., Kumar, R., \& Pal, D. (1989). Changes in sugars, organic acids, amino acids, lipid constituents and aroma characteristics of ripening mango (Mangifera indica L.). Journal of Food Science and Technology, 26, 308-313.

Sereno, A. B., Bampi, M., dos Santos, I. E., Ferreira, S. M. R., Bertin, R. L., \& Krüger, C. C. H. (2018). Mineral profile, carotenoids and composition of cocona (Solanum sessiliflorum Dunal), a wild Brazilian fruit. Journal of Food Composition and Analysis, 72, 32-38. http://dx.doi.org/10.1016/j.jfca.2018.06.001

Silva, Q., Moreira, Q., \& Melon, A. (2012). Alimentos e nutrição. Brazilian Journal of Food and Nutrition, 23, 73-81.

Tripathi, S., Suzuki, J. Y., Carr, J. B., McQuate, G. T., Ferreira, S. A., Manshardt, R. M., Pitz, K. Y., Wall, M. M., \& Gonsalves, D. (2011). Nutritional composition of Rainbow papaya, the first commercialized transgenic fruit crop. Journal of Food Composition and Analysis, 24(2), 140-147. http://dx.doi.org/10.1016/j.jfca.2010.07.003

United States Department of Agriculture - USDA. (2018). Food composition databases. Washington. Retrieved in 2020, July 8 , from https://ndb.nal.usda.gov/ndb/foods/show/09139 
Development and application of a liquid chromatography-mass spectrometry method for the determination of sugars and organics acids in araza, ceriguela, guava, mango and pitanga

Cardoso, P. C. et al.

Valente, A., Albuquerque, T. G., Sanches-Silva, A., \& Costa, H. S. (2011). Ascorbic acid content in exotic fruits: A contribution to produce quality data for food composition databases. Food Research International, 44(7), 2237-2242.

http://dx.doi.org/10.1016/j.foodres.2011.02.012

Wilson, C. W., Shaw, P. E., \& Campbell, C. W. (1982). Determination of organic acids and sugars in guava (Psidium guajava L.) cultivars by high-performance liquid chromatography. Journal of the Science of Food and Agriculture, 33(8), 777-780. http://dx.doi.org/10.1002/jsfa.2740330815

Zaky, A. S., Pensupa, N., Andrade-Eiroa, Á., Tucker, G. A., \& Du, C. (2017). A new HPLC method for simultaneously measuring chloride, sugars, organic acids and alcohols in food samples. Journal of Food Composition and Analysis, 56, 25-33.

http://dx.doi.org/10.1016/j.jfca.2016.12.010

Financiamento: Coordenação de Aperfeiçoamento de Pessoal de Nível Superior (CAPES - Código do financiamento: 001) e

Fundação de Amparo à Pesquisa do Estado de São Paulo

(FAPESP - Processo n. 2018/194410). 
Development and application of a liquid chromatography-mass spectrometry method for the determination of sugars and organics acids in araza, ceriguela, guava, mango and pitanga

Cardoso, P. C. et al. 